\title{
The location of new residential areas and the preservation of open space: experiences in the Netherlands
}

\section{Piet Rietveld}

Department of Regional Economics, Faculty of Economic Sciences, Business Administration and Econometrics, Vrije Universiteit, Amsterdam, The Netherlands; e-mail: prietveld@feweb.vu.nl

\section{Alfred J Wagtendonk}

Spatial Information Laboratory, Faculty of Earth and Life Sciences, Vrije Universiteit, Amsterdam, The Netherlands; e-mail: alfred.wagtendonk@ivm.falw.vu.nl

Received 21 August 2003; in revised form 24 December 2003

\begin{abstract}
As a consequence of the ongoing growth in demand for houses in the Netherlands over recent decades, the fraction of the total surface used for residential purposes has expanded rapidly. The location patterns of new residential construction are the result of various forces: government intervention aiming at the preservation of open space via zoning, new-town, and 'compact-city' policies, and market forces reflecting preferences on the demand side (households and real-estate developers). The main factors influencing the location of residential construction are analysed by means of a statistical analysis. The most significant variables appear to be the proximity of a location to existing residential areas, location in new towns receiving government support, the accessibility of workplaces, distance to railway stations, and, to a lesser extent, the accessibility of nature, surface water, and recreational areas.
\end{abstract}

\section{Introduction}

Even in a densely populated country such as the Netherlands - it has the highest population density of Europe, with about 380 persons per $\mathrm{km}^{2}-6.5 \%$ of the total land area is used for residential purposes and about $83 \%$ of the area consists of open space. However, compared with other European countries the proportion of open space is low. In Denmark this share is estimated to be about $91 \%$ and in the United Kingdom approximately $90 \%$ (Ottens, 1999). The issue of open space is closely related to the density of settlements. Low-density urban development, usually associated with urban sprawl, is often considered inefficient. It increases transportation costs, consumes excessive amounts of land, thus reducing open space, and adds to the cost of providing and operating public utilities and public services (Peiser, 1989). However, low densities may be in accordance with the desires of households to live in a spacious environment.

In densely populated countries with a limited amount of open space and natural areas the fragmentation of open space is a particular concern. Small and vulnerable natural areas are increasingly split up and isolated and lose their viability. At the same time, civilians lose even more of their (already limited) possibilities for enjoying free open space and nature. In addition, excessive suburbanisation contributes to the decay of central cities by reducing the incentive to redevelop land near the centre (Brueckner, 2000).

Over recent decades many countries have therefore developed land-use policies for growth management, aimed particularly at the prevention of urban sprawl. The question of whether policies aimed at preventing spatially discontinuous development will lead to land-use patterns in which densities of settlements will be higher than they would be in the absence of such a policy is, however, still a subject of discussion. Peiser (1989), for example, argues that a competitive land market will achieve the desired result of higher density developments precisely by the process associated with urban sprawl-namely, spatially discontinuous development followed by later infill. True or not, Peiser considers urban sprawl mainly as it influences urban density and the total 
volume of open space and does not consider the other effects of urban sprawl that are related more to spatial patterns having direct effects on traffic flows or on the fragmentation of natural areas. In the United States the debate on laissez-faire and urban sprawl compared with planning regulation and concentrated development is still ongoing (for instance, see Gordon and Richardson, 1997; Hayward, 1996; Nelson, 1999). Brueckner (2000) treats the subject not by questioning the spatial expansion of cities itself but by questioning the speed of this expansion and the involvement of different market failures. He mentions, for example, the failure to take into account the social value of open space when it is converted to urban use and the failure of individual commuters to recognise the social costs of congestion created by their use of the road network. The third failure he mentions is related to the real estate developers, who do not take into account all the public infrastructure costs generated by their projects.

Outside the United States more consensus exists over the need to curb urban sprawl and encourage compact forms of urban development that contribute to urban sustainability (Razin, 1998). It should, however, be noted that the US situation with (on average) extremely low building densities is difficult to compare with the European situation. For example, in the United States in the 1990s the density of housing in the central city was only 4.1 houses per hectare of urban area, with a compact density of such housing being defined as 13-15 houses per hectare (Gordon and Richardson, 1997). The average density of housing in 1989 in the Netherlands on the contrary was 27 houses per hectare of residential area, and 37 houses per hectare of residential area for the urbanised western part of the Netherlands.

Our aim in this paper is to analyse the forces influencing the spatial location of expansion of the housing stock in the Netherlands. The impact of various location factors is taken into account. Proximity to existing urban areas is the first factor considered. The extent to which this factor is important obviously has consequences for the deterioration of open space. In addition, factors such as accessibility to work, nature, and transport nodes (in terms of rail and expressway exits) will be taken into account. In section 2 we provide a theoretical background, including a short survey of land-use models. In section 3, the goals and operating principles of Dutch spatial policy as applied to the construction of new dwellings are explained. In section 4 the model structure is specified. The results of the modelling exercise are given in section 5 , and conclusions are drawn in section 6.

\section{The development of urban land uses}

A main starting point for the analysis of urban land use is the Alonso model (see Alonso, 1964; Muth, 1969). This model explains how the bidding for land by various types of actors (households grouped according to income level, firms grouped according to sector) results in land-use patterns, with various types of activities taking place in particular zones. These models can in principle also be used to predict the spatial effects of urban economic growth in relation to an increase of income or population. In the simple monocentric model, urban economic growth will manifest itself by an outward shift of the city fringe (Fujita, 1989).

If we take the monocentric city model as a starting point, a number of extensions are possible. For example, public facilities, infrastructure, and environmental quality will lead to departures from the usual bid-price patterns so that concentrations may occur near places with a particular quality (Fujita, 1989). Another useful extension is the formulation of models describing systems of cities where the migration of firms and households takes place (Henderson, 1985). The work of Garreau (1988) on edge cities has stimulated the development of urban land-use models with multiple nodes. 
For example, see the work of Henderson and Mitra (1996) and of Glaeser and Kahn (2003), who analyse the location choice of real-estate developers.

Governments play a role in these models, in various ways. One role of government is as a supplier of public facilities and infrastructure. In addition, governments may intervene in land-use planning to correct for environmental externalities. A well-known example is zoning, where certain activities are not allowed in particular areas in a city. McCann (2001) discusses the consequences of zoning for land use and rents in these areas and at other places in the city. Another instrument for intervention is greenbelt policy, to keep areas around an existing urban centre open. This induces higher rents within the city and at the outer edge of the greenbelt. A third instrument, also having the aim of preserving open space, is the use of subsidies to stimulate concentrated growth in new towns (growth centres).

The above theories on land use in urban systems - although there may be many variations among them-share a number of features. First, they are based on a formulation of continuous space, where each point has a distinct quality, as opposed to formulations of discrete space, with a finite number of zones. Second, the models are deterministic and the landowner will always accept the bid of the highest bidder. In addition, most contributions ignore the issue of urban history: when one of the parameters governing the system changes, a new equilibrium land use evolves that does not depend on the existing land-use pattern, implying that transition costs do not matter.

These three features make this approach less useful for empirical research. Therefore, it is no surprise that other modelling approaches have been developed that are more suitable for empirical research. An important example consists of land-use transport models (Anas, 1982; Hayashi and Roy, 1996; Martinez, 2000). These models are usually formulated as dynamic models, so that at the beginning of each period households and firms may decide to relocate as a response to changes in infrastructure networks or particular exogenous variables. These locational decisions are usually framed in logit-based probabilistic terms. Some of these models are based on explicit market equilibria, land prices playing an important role. Comparing these approaches with the original Alonso model we note that land-use transport models make use of discrete spatial units. As data sources tend to be zone based, this makes these models easy to feed with empirical data. Second, these models are stochastic. They are usually based on random utility theory, where the bid depends not only on objective features of locations but also on unobserved idiosyncratic factors. This allows the use of powerful and easy-to-handle discrete choice models (see McFadden, 1978). Third, history plays a role, as dynamic model formulations are used whereby in each period the existing stock of investments is relatively fixed. Thus, the models focus on changes in stocks, not on the stocks themselves.

The model that will be used in this paper in sections 4 and 5 can be classified into the second modelling approach. It is based on discrete choice modelling, addresses discrete spatial units, and takes into account the difference between stocks and flows (new construction). It will be applied to Dutch data on residential construction. Therefore, we first give a broader introduction of the policy context for the housing market in the Netherlands.

\section{Public and private interests in residential construction: the Dutch case}

Given the externalities involved in land use it is no surprise that the Dutch government has opted for rather strong involvement in the planning of residential construction, both in terms of the total volume of land involved and in terms of the location. We will not provide a detailed discussion here of spatial planning policies during past decades as this can be found in various policy documents of the Ministry of Housing, 
Spatial Planning and the Environment (VROM, 1960; 1966; 1974; 1988; 1990; 2001). A broad range of goals has been formulated in the course of time, such as the strong positioning of the Dutch city system in an international context, improvements to the international accessibility of cities and main ports, nature conservation, the reservation of sufficient space for residential and industrial purposes, and the achievement of spatial diversity and variety. In particular, we would mention the following objectives. First, there is an objective to preserve as much as possible the volume of open space in the main parts of the country (for example, see VROM, 1974, pages 130 - 132 and 151 - 153; 1990, page 20; 2001, page 139). The second objective is to arrive at a spatial structure where the fragmentation of open space is avoided. The third objective is to create favourable conditions for efficient spatial interaction patterns where there is scope for transport modes such as the car and, especially, for other modes [public transport and the bicycle (see VROM, 1974, page 151)]. In addition to these objectives, related to the public interest, there are, of course, the interests of individuals living in the dwellings, or waiting for a dwelling to be realised. These objectives have been pursued with varying intensity during past decades. During some periods, individual preferences have received more attention than have public objectives. Also, within the group of public policy objectives, the emphasis has varied from time to time.

Note that the first public policy objective relates to the total volume of open space, whereas the second objective concerns the spatial distribution of open space. The first objective has stimulated the design of residential areas with relatively high densities in terms of the number of dwellings per hectare (see VROM, 1990, page 43). The second objective led to a policy to concentrate residential construction in particular centres. The third objective has received two interpretations: clustered deconcentration and the creation of compact cities. An example of clustered deconcentration is the growthcentre policy, which was the dominant policy concept during the 1980s. New towns have been created at some distance from the larger cities, usually with good railway connections to the large cities. The second interpretation of this objective, to create compact cities, has been for residential construction to take place within and immediately adjacent to large cities in order to create opportunities for nonmotorised modes of transport [the modal share of the bicycle is very high in the Netherlands (for example, see Clark and Kuijpers-Linde, 1994)] and for public transport within the urban area. Another potential advantage of the compact-city concept is that distances from the newly created residences to the main location of employment are relatively short. This potential is not always utilised, however, as during the 1990s female participation in the workforce increased substantially, leading to two-earner households for which it was difficult to find two jobs close to the residence. The compact-city policy has been the dominant policy concept since about 1985 (for example, see Needham et al, 1993). The government memorandum of 2001 (VROM, 2001) has replaced it with the notion of 'urban networks'.

The government has indeed achieved some success in these policy objectives. For example, the average parcel size in the Netherlands is probably considerably lower than those in neighbouring countries. Internationally comparable data on the parcel size of dwellings are not available, but an indication of the small parcel size in the Netherlands is that the share of detached dwellings is very low [14\%, compared with $27 \%$ in other European countries (SCP, 2000)]. This implies that open space has been saved. In addition, the policy of concentrating residential construction in particular places has also been successful to some extent. Some new towns have indeed experienced rapid growth, implying that a strongly dispersed pattern of residential construction has been avoided (see Bontje and Ostendorf, 1999). The success in achieving the third objective has been much more limited, however. New towns experienced very rapid growth 
during the 1980s, but many people living in these cities use the car instead of public transport to travel to the main city, implying considerable environmental and congestion problems. Also, the more recent creation of housing near large cities does not necessarily lead to short commuting distances. The polycentric urban system of the western part of the Netherlands implies that there are usually a good number of centres of employment within a range of some $40 \mathrm{~km}$ from a certain city. A strategy of residential construction near large cities does not guarantee that residents will work in the same city (Maat, 1999; Van der Laan et al, 1998). Another problem the government has had to face is that the restrictive policies keep land prices for residential construction high (Aalbers et al, 1999; Buurman and Rietveld, 2000); also, many consumers are not satisfied with the size of the parcels and the resulting quality of the dwellings. Thus there is a certain tension between private (consumer) and public interests, and it is not clear that the present patterns of location of residential construction and the size of the parcels reflect a proper balance between the two.

It is important to emphasise that the government is not a monolith: national, regional, and local governments play distinct roles in land-use planning. Local governments develop land-use plans, specifying where residential construction is allowed. These local plans have to be consistent with the more global land-use policies formulated at the provincial and national level. Local plans require approval by the provincial government. Conflicts between higher and lower levels of government may easily arise in this context. A frequently observed case is that municipalities tend to want to allow the construction of substantial numbers of dwellings, whereas higher-level governments try to prevent such development because it would lead to fragmentation of open space. ${ }^{(1)}$

Several types of government involvement in the land market can be distinguished in addition to zoning: governments may impose a permitting system in which the construction of new residential areas is permitted in some areas but restricted in others; governments may also intervene by subsidising and facilitating the construction of new dwellings at particular locations by means of so-called location subsidies. Growth centres in particular received substantial subsidies in this context during the 1970s and up to 1985. The difference between these approaches is that permission to construct new residences does not necessarily imply that such construction actually takes place. There may be a lack of private sector exploitation of the opportunities offered by permission to use agricultural land for residential construction. In the case of subsidies and facilitation, the government is much more heavily involved. Involvement can take the form, among other things, of subsidies for the construction of the social rented share of the housing market. A system of annual housing subsidies existed during the whole period considered but was terminated in 1995. In 1996 the share of the social rented sector in the total housing stock in the Netherlands was $41 \%$, much higher than the EU average of $14 \%$ (SCP, 2000).

Governments cannot ignore the interests of individuals in land-use policies. In the case of permitting policies, governments will find that at certain locations no residential development will occur even though it is permitted. In this case, failure to recognise consumer preferences is not a risk. In the case of policies where governments are more intensely involved there is, of course, a risk of overinvestment in housing of a certain quality and at certain locations, leading to high rates of vacancies. Failure to recognise preferences may also demonstrate itself in a lack of interest on the side of the private sector in investing in the places where the government has planned investment.

The historical development of residential construction is the result of active policies (via facilitation and subsidies), permitting policies, and restrictive policies. In the

(1) Increasingly, the contrary can be observed: small municipalities oppose growth tasks imposed on them because their residents put greater weight on the advantages of small municipalities. 
construction activities that take place under an active policy regime one may expect a strong representation of public sector preferences, whereas construction that takes place under a permitting policy would be an expression of consumer preferences. There is a danger of oversimplication, however. First, public policies in the form of facilitation and subsidies do not necessarily ignore consumer preferences. For example, the success of the growth-centre policy is probably partly attributable to the fact that it resulted in dwellings that were attractive to many consumers. Second, when governments are very restrictive in their planning policies, permitting policies may result in construction activity that is only second best from a consumer's point of view: the really attractive locations are not available. Obviously, it is difficult to disentangle where the resulting patterns of residential construction reflect the preferences of the public sector and where they reflect those of consumers.

We note in passing that, in addition to the above cases, there are further housingmarket imperfections. One that is of particular relevance concerns the fundamental fact that housing stock has a very long lifetime. Annual construction volumes are usually below $2 \%$ of the total stock in the Netherlands and at present they are as low as $1 \%$. As it is impossible to change the location of the current stock, and as quality changes are costly, it is almost impossible to arrive at an appropriate match between demand and supply in the market. Obviously, it is not easy to achieve a match that is appropriate from a long-run perspective.

\section{Model of location choice for the construction of housing}

We will use detailed grid-based data on the construction of new housing in the Netherlands during a fifteen-year period. This will allow us to analyse the spatial choices of developers and governments on where to build (or allow to build) new housing, and where not. Most housing-market research focuses on the choices of households between dwellings of various types [for example, see the work of van Lierop (1985), van Ommeren (2000), and van der Vlist (2001) who based their research mainly on Dutch housing-market surveys]. This concerns the choice between existing residences. The choices of developers on where to build new housing have received much less attention in the literature. The two are, of course, related, but the data on which they are based are very different. A focus on choice of where to locate residential construction is uncommon.

In the Netherlands, most new construction of housing takes place by real estate developers, who commission the building of housing at particular sites. Therefore, we formulate our model from the perspective of a developer who compares all potential locations from the viewpoint of their locational attractiveness. We assume that developers consider in the first instance the interests of the buyers of houses. If they were to ignore these interests, they would soon go bankrupt. However, as indicated by Needham et al (1993), the developers are large enough to have market power, which allows them some freedom to manoeuver so that the projects they commission are not necessarily a perfect representation of consumer preferences. Some developers are connected to construction companies (with the important objective of continuity of construction projects), some are connected to banks and insurance companies (with the important objective that buyers will borrow money from the bank), and some are independent. Also, as emphasised in section 3, governments have tools to influence developers' choices.

In our model, building locations are compared by the developer from the perspective of their suitability for development. Consider a number of grid cells, $c=1, \ldots, C$. Given the small size of the grid cells in the study, the total number of cells is very large (about 140000 ). The suitability (or utility) of grid cell $c$ for development is represented by index $s_{c}$. 
This suitability index is assumed to depend on a number of features, $x_{c k}(k=1, \ldots, K)$, of grid cell $c$. Among these features are accessibility, the quality and area of nature adjacent to the site, and the price of acquiring the land. These features reflect the attractiveness of the locations to future residents and also the costs of acquiring the land. If we assume that the suitability of the land depends in a linear way on the features considered, we arrive at the following equation:

$$
s_{c}=b_{1} x_{c 1}+b_{2} x_{c 2}+\ldots+b_{K} x_{c K}, \quad \forall c,
$$

where $b_{1}, \ldots, b_{K}$ are coefficients. The developer is assumed to compare all potential locations $c$ according to their suitability $s_{c}$. The higher the suitability of $c$, the higher the probability that development will take place in $c$. A simple way to link suitability to the probability of actual development is to adopt the logit model. This means that developers are assumed to have idiosyncratic preferences, implying that they base their choice on the suitability indicator $s_{c}$ plus a stochastic term $\varepsilon_{c}$ that represents their departure from the structural term $s_{c}$. Then, when $\varepsilon_{c}$ is distributed according to the Weibull distribution, the probability $P_{c}$ that location $c$ is chosen by a developer can be represented by the logit model (see, Cramer, 1991). This probability is given as follows:

$$
P_{c}=\frac{\exp s_{c}}{\exp s_{1}+\exp s_{2}+\ldots+\exp s_{C}}, \quad \forall c .
$$

Thus, we arrive at the logit model, which is indeed a cornerstone of the empirical landuse models reviewed briefly in section 2 . The specific feature of our model is that we consider the choices of developers of new sites, whereas usually the logit model is used for residential choices regarding existing dwellings. Equation (2) is based on the implicit assumption that all cells are equally large. As not all grid cells are of equal size - those located at the border are smaller, because the external part has been excluded - this equation has to be modified.

Let $L_{c}$ denote the size of cell $c$; then the adjusted formulation reads as follows:

$$
P_{c}=\frac{L_{c} \exp s_{c}}{L_{1} \exp s_{1}+L_{2} \exp s_{2}+\ldots+L_{C} \exp s_{C}}, \quad \forall c .
$$

Clearly, when all grid cells are of equal size, equation (3) will reduce to equation (2).

As explained in section 3, the patterns of the location of dwellings realised will be influenced by government intervention. This implies that the suitability indicators $s_{c}$ as used here are assumed to reflect the joint outcome of the preferences of the developer, consumers, and government. For example, individual preferences may favour locations far away from existing cities, whereas it is the government's objective to stimulate construction near the large cities. As government has a stronger influence on the construction of multifamily housing compared with its influence on single-family housing, it will be useful to apply this distinction in the empirical part of the study. ${ }^{(2)}$

Another remark about the model is that, in its present formulation, empty spaces are assumed to be filled at once. Thus, no account is taken of the strong historical component in human settlement patterns: factors that played a role centuries ago in the growth of a city may have had a strong impact on the current settlement system, which in its turn will have a strong impact on its future development. Therefore it is better to use the model in such a way that it takes the settlement pattern at a certain point in time as given and uses this as a starting point to explain the expansion (or contraction) of space used for residences. This is indeed what is done in our 
empirical analysis. Thus, we do not investigate land use for residential purposes per se but changes in this land use. This means that $L_{c}$ in equation (3) is interpreted as the total amount of land available for additional residential construction; the current use of land for residences is excluded from $L_{c}$. This means that although very high values for $s_{c}$ may be observed within urban areas, the total construction volumes will be relatively small, as the available land $L_{c}$ is small.

The data on the dependent variables on which the estimations are based relate essentially to the total surface of the grid cells $c$ that came into use for residential purposes during a certain period. In order to make these data compatible with our model we assume a certain standard area of land per housing unit. This leads to the need to distinguish various dwelling types, as area per dwelling varies among dwelling types. The dwelling types used are further discussed in section 5.

\section{Empirical results}

In this section we carry out a statistical analysis to explain the locational pattern of the increase of single-family and multifamily dwellings between 1980 and 1995. The period considered here starts with the last part of the growth-centre policy period $(1980-85)$, a policy that was relatively successful in terms of construction volumes in the growth centres but that weakened the position of the large cities. Growth-centre policy started in the 1970s and continued until 1985. Growth centres received substantial subsidies. The second part of the period (after 1985) was dominated by compact-city policies. The end of the period considered (1995) was also the year in which so-called VINEX policies started to be implemented (see Needham, 1997; VROM, 1990). Another important point is that housing-related subsidies-provided by the central government-played an important role until about 1990. This obviously gave the central government a strong position during this period in realising construction at locations that were in agreement with its policy objectives. Also, the position of housing corporations underwent considerable changes at about the same time. Thus, the results for the period 1980-95 cannot simply be transferred to the period thereafter. For example, annual housing subsidies were terminated in 1995.

The statistical relations are analysed with the help of the model formulated in section 4. For details on the methodology and the data used we refer the reader to an earlier publication (Wagtendonk and Rietveld, 2000).

Two types of dwellings are distinguished: single-family dwellings (including detached, semidetached, farmhouse, and terraced houses), and multifamily dwellings (including flats, nonindependent accommodation, and other dwellings). Digital maps with the spatial distribution of these two types of dwellings were made by combining parcel coordinate files (PAP files) with residential statistics from Statistics Netherlands (CBS, 1997). In figure 1(a) it can be seen that single-family dwellings in 1980 were distributed fairly evenly over different urban concentrations in the Netherlands, whereas from figure 1(b) it can be seen that the multifamily dwellings were concentrated mainly in the three major cities of the Randstad.

\subsection{The dependent variables}

As explained in section 4, the distribution of the existing dwelling stock is not a function of recent driving forces but of historic circumstances, which may date back centuries. Therefore we have chosen the recent dynamics, between 1980 and 1995, of residential development as our focus. The beginning of this period was marked by an emphasis on growth centres and new towns, after which the concept of compact urbanisation gained importance. 


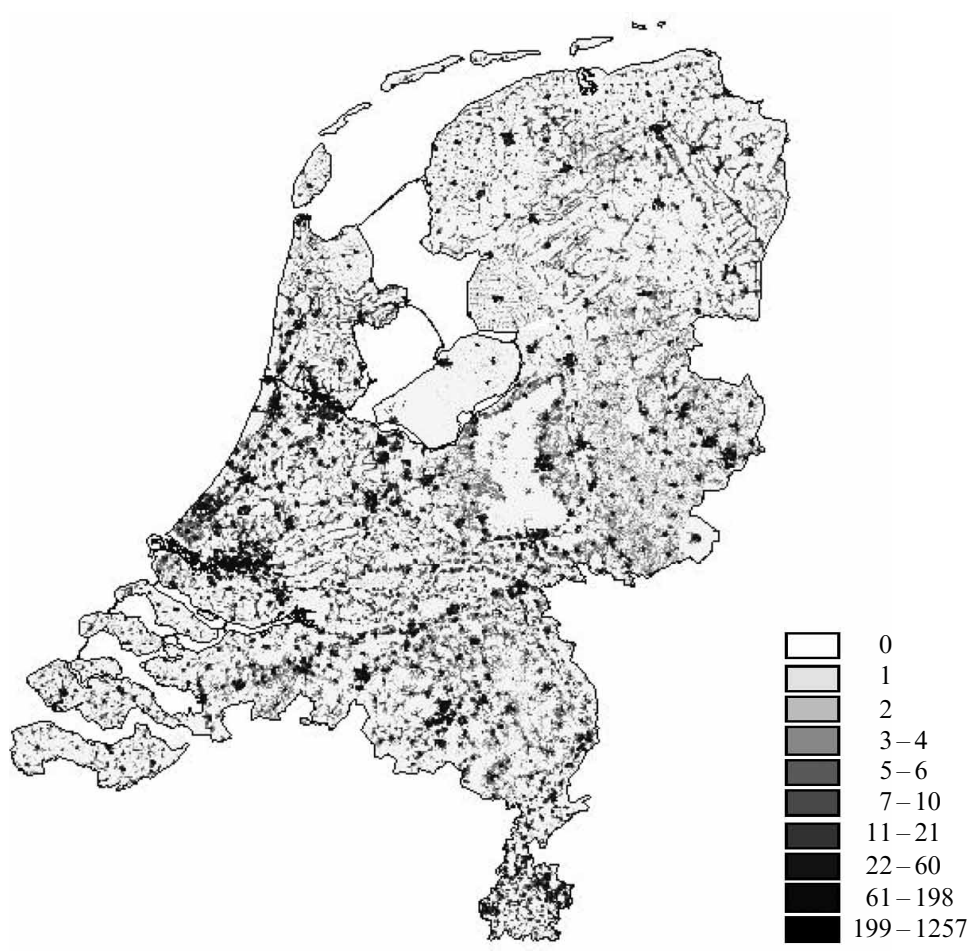

(a)

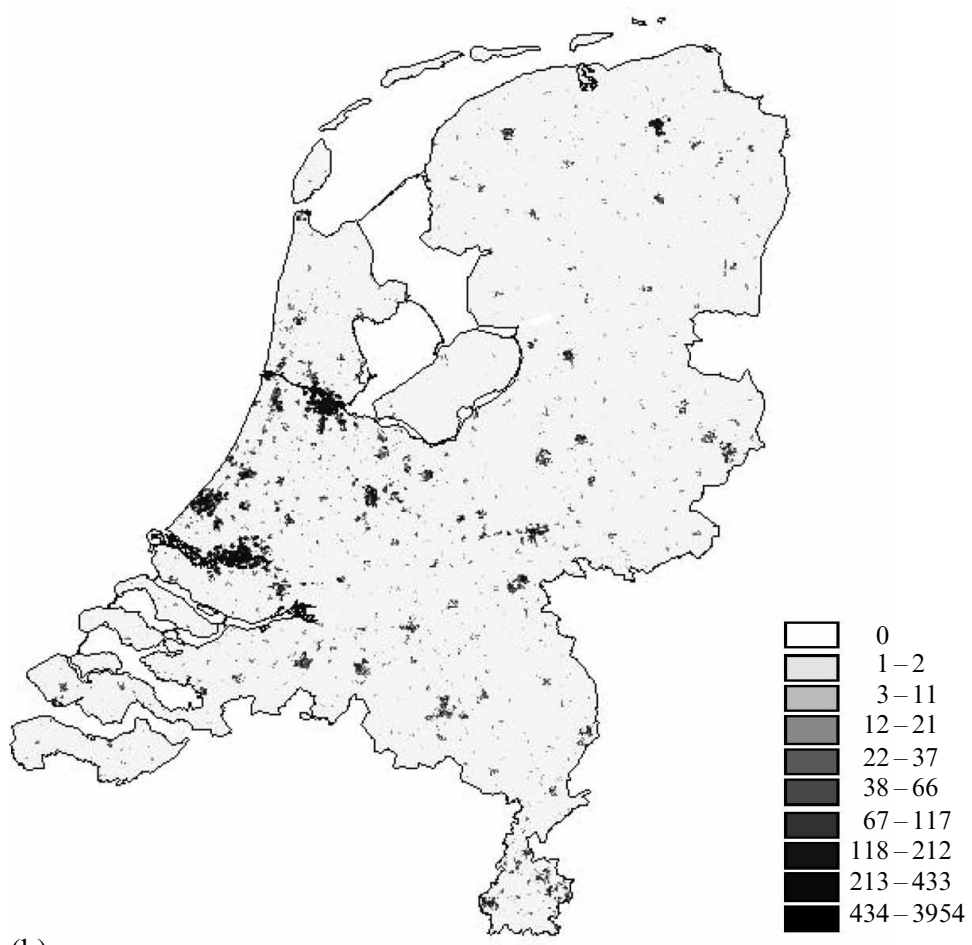

(b)

Figure 1. Distribution of (a) single-family dwellings and (b) multifamily dwellings in 1980: number of dwellings per square cell (measuring $500 \times 500 \mathrm{~m}$ ). 
For the calculation of the dependent variables, a number of assumptions were made. It was assumed that there was a maximum to the increase of dwellings per cell, equal to or smaller than the observed maximum number of dwellings per cell in 1995 (1280 single-family dwellings, and 3846 multifamily dwellings). The possible number of new dwellings was divided by the area that was available for new building activities. The available area was 25 ha per grid cell minus the existing residential area, minus the existing area for work, minus the area occupied by surface water, such as lakes, rivers, and canals. These mathematical operations result in the calculated maximum possible growth in number of dwellings per grid cell. Division of the observed number of new dwellings and the maximum possible number of dwellings yields the share of space that was eventually used for construction during this period.

\subsection{Independent variables}

The aim of our analysis is to find the determinants of locational choice in the construction of housing. These determinants relate to available space, spatial policy, and personal preferences (of real-estate developers and their target markets). The following driving factors can be distinguished.

First, proximity to and concentration of existing residential areas (maximum radius $500 \mathrm{~m}$ ) is important. This variable is measured as the number of dwellings per hectare in the zones surrounding a given zone. Although the search radius of people looking for a dwelling is rather large (Goetgeluk, 1997), in the Netherlands the majority of people move within their own neighbourhood or municipality. New residential areas situated near existing residential areas may therefore be expected to be attractive to local residents. Also, the costs of facilities for a new residential area will be lower if the area is connected to an existing residential area. In addition, building close to existing residential areas is in harmony with government objectives to avoid fragmentation of open space and to stimulate short-distance spatial interaction, encouraging the use of nonmotorised transport modes.

Second, accessibility to employment (maximum radius $60 \mathrm{~km}$ ) is important. People attach value to the amount of and accessibility to work in their surroundings, but they accept to a certain extent the disadvantages of commuting if there is a better living environment and cheaper housing at the home location (Mills and Hamilton, 1994). This implies that the distance to work should be weighted according to a certain distance-decay function and should depend on the concentration of available work. Various investigators have pointed out that, for most people, the maximum acceptable commuting time in the Netherlands is between 30 and 60 minutes (Gerritsen, 1997). The average commuting time is about 20 minutes (Rietveld, 2000). This is confirmed by Van Ham (1999), who shows that the majority of jobs are found within a short distance of homes.

Third, the accessibility (maximum radius $15 \mathrm{~km}$ ), quality, and size of natural area, forest, and recreation areas (including wetlands) are important. In addition, leisure, open space, and recreational possibilities are relevant determinants.

Fourth, distances to railway stations and to expressway exits are important. Recall that the distances to the closest entry points of the railway and expressway systems are used to measure the overall accessibility of a location.

Fifth, the proximity to railways, expressways, and airports (measured in terms of the presence of such infrastructure in a grid cell) is important. Such infrastructure can be a negative factor in terms of noise, air pollution, or visual pollution (measured as the presence of these infrastructure types in a zone).

Sixth, a location in a new town or growth centre is important. The public sector has a strong influence on the spatial distribution of residential construction via new-town policies. 
In the period studied here a considerable part of the building programme was concentrated in new towns and growth centres (Faludi and Van der Valk, 1994).

Note that distance to railway stations and proximity to railways seem to be contradictory variables. The difference between the two is that the first measures distance from a zone to the nearest railway station, whereas the second considers the presence of a railway line in a zone. This formulation allows one to distinguish between the positive aspects of infrastructure (a short distance to a node implies high accessibility) and the negative aspects of infrastructure (the presence of infrastructure in a zone may lead to noise problems and so on). Details of the measurement of the above variables are given in an earlier publication (Wagtendonk and Rietveld, 2000). For the computation of accessibility variables, we used gravity-type indicators (see Hilbers and Verroen, 1993; Rietveld and Bruinsma, 1998).

\subsection{Correlation analysis}

Our first step was to use correlation analysis to find the most significant relationships. This was done by testing the strength of the relationship between each of the dependent variables (increase in dwellings) and the independent variables, such as accessibility to recreational areas, expressed in the correlation coefficient. Given the large number of observations (covering about 140000 grid cells) it is no surprise that many significant relationships were found. The results of the correlation analysis shown in table 1, confirm most of the expected relations. A strong positive relation is found between

Table 1. Correlation between the dependent variable (residential construction expressed as increase in number of dwellings, 1980-95) and various explanatory variables.

\begin{tabular}{lll}
\hline Independent variable & \multicolumn{2}{l}{ Dependent variable } \\
\cline { 2 - 3 } & single-family dwellings & multifamily dwellings \\
\hline Proximity to existing housing stock & & \\
$\quad$ single-family dwellings & 0.412 & 0.282 \\
multifamily dwellings & 0.174 & 0.302 \\
Accessibility to labour, by sector & & \\
$\quad$ construction & 0.125 & 0.120 \\
retailing & 0.127 & 0.128 \\
wholesale & 0.113 & 0.115 \\
manufacturing & 0.133 & 0.113 \\
knowledge & 0.115 & 0.134 \\
public sector & 0.128 & 0.131 \\
agriculture & 0.070 & 0.047 \\
$\quad$ transport & 0.115 & 0.122 \\
Accessibility to natural areas & & \\
$\quad$ forest & -0.002 & -0.013 \\
forest, leisure & 0.065 & 0.056 \\
$\quad$ nature, dry land & 0.001 & 0.004 \\
$\quad$ nature, wetland & -0.012 & -0.001 \\
$\quad$ water & 0.042 & 0.050 \\
Euclidian distance to infrastructure & & -0.054 \\
$\quad$ expressway exit & -0.088 & -0.072 \\
railway station & -0.105 & 0.006 \\
Presence of infrastructure in zone & & 0.037 \\
$\quad$ expressway & 0.046 & 0.028 \\
railway & 0.039 & 0.037 \\
Status of planning zone: & 0.084 & \\
$\quad$ new town & & \\
growth centre & 0.048 & \\
& &
\end{tabular}


the increase in the number of single-family dwellings and the proximity of existing single-family dwellings and a considerably weaker relation for increase in the number of single-family dwellings and the proximity of multifamily dwellings. These differences are confirmed by the different spatial distributions of single-family and multifamily dwellings (see figure 1). Similar relations are found for the increase in the number of multifamily dwellings and the proximity of existing multifamily dwellings. Relatively strong positive correlations for both dwelling types are found relative to accessibility to jobs in the various sectors. The differences between the sectors are rather small, however. The only exception is, not surprisingly, the agricultural sector, which has a lower correlation with residential construction compared with other sectors.

This list of simple correlations is interesting but, given the interdependences between variables, it is of little value as an explanatory analysis of residential construction patterns. For example, the positive correlation between presence of expressways and railways and residential construction may be somewhat surprising, because one would expect that noise problems would make zones close to such infrastructure less attractive for residential development. A possible explanation is that in densely populated areas the infrastructure densities will also be higher, so that what one observes is not so much a direct effect between infrastructure presence and residential construction but an indirect effect. To take care of such indirect effects, we also carried out an explanatory analysis by using the model outlined in section 4. Given the large number of explanatory variables and the high correlations between many of them it is not feasible to use all these variables in a multiple regression. Our regression analysis is therefore based on a selection of these variables (for details on the stepwise approach taken, refer to Wagtendonk and Rietveld, 2000).

\subsection{Logit analysis of residential construction patterns}

The second step of the statistical analysis was the estimation of the logit model described in section 4. Because it is expected that the variables will have different relations to the dependent variables under different socioeconomic conditions and spatial policies, the regression analyses were repeated but divided into three regional zones, the Randstad (the Western part of the country, where the larger cities are located), the 'intermediate zone', and the 'peripheral zone'. Because we did not find clear differences between the intermediate zone and the peripheral zone we decided to combine these into one single zone ('the rest of the Netherlands'). For each set a group of 9-11 explanatory variables was produced, which are presented in table 2 . In the following sections we will discuss the results for single-family and multifamily dwellings in the Randstad and the rest of the Netherlands.

\subsubsection{The Randstad}

A remarkable result for single-family dwellings in the Randstad is the absence of the explanatory variable relating to accessibility to jobs. A possible explanation for this result is the good availability of jobs at all places in this polynuclear region and the high density of the infrastructure network linking residences to work areas. The exact location in the Randstad seems to be largely irrelevant for this factor. Accessibility to natural areas does not play a large role in this part of the country. The negative sign found for single-family dwellings may point to restrictive government policies near natural areas. There are not many natural areas in this part of the country, but, as far as they exist (lakes and dunes), residential development is discouraged in these areas or in their immediate neighbourhood. In grid cells where expressways and railways are present, the probability that open land will be converted into residential use is smaller than in other cells. This underlines the idea that noise is an important location factor at the local scale (an exception is the impact of railways on increase in multifamily dwellings). Distance to 
Table 2. Logit analysis ( $B$-statistics) of residential construction in the Randstad and the rest of the Netherlands.

\begin{tabular}{|c|c|c|c|c|}
\hline \multirow{2}{*}{$\begin{array}{l}\text { Explanatory } \\
\text { variable }\end{array}$} & \multicolumn{2}{|l|}{ The Randstad } & \multicolumn{2}{|c|}{ The rest of the Netherlands } \\
\hline & $\begin{array}{l}\text { single-family } \\
\text { dwellings }\end{array}$ & $\begin{array}{l}\text { multifamily } \\
\text { dwellings }\end{array}$ & $\begin{array}{l}\text { single-family } \\
\text { dwellings }\end{array}$ & $\begin{array}{l}\text { multifamily } \\
\text { dwellings }\end{array}$ \\
\hline Intercept & $\begin{array}{l}-7.020 \\
(-389.6)\end{array}$ & $\begin{array}{l}-20.353 \\
(-255.6)\end{array}$ & $\begin{array}{l}-11.811 \\
(-462.2)\end{array}$ & $\begin{array}{l}-15.021 \\
(-329.8)\end{array}$ \\
\hline $\begin{array}{l}\text { Accessibility to employment } \\
\text { manufacturing sector }\end{array}$ & na & na & $\begin{array}{l}0.283 \\
(121.3)\end{array}$ & na \\
\hline knowledge sector & na & $\begin{array}{l}0.996 \\
(160.0)\end{array}$ & na & $\begin{array}{l}0.345 \\
(79.3)\end{array}$ \\
\hline $\begin{array}{l}\text { Accessibility to natural areas } \\
\text { forest, leisure }\end{array}$ & $\begin{array}{l}-0.023 \\
(-27.5)\end{array}$ & na & $\begin{array}{l}0.035 \\
(39.9)\end{array}$ & na \\
\hline forest & na & $\begin{array}{l}0.064 \\
(36.0)\end{array}$ & na & na \\
\hline nature, wetland & na & na & $\begin{array}{l}0.072 \\
(69.1)\end{array}$ & $\begin{array}{l}0.106 \\
(39.6)\end{array}$ \\
\hline \multicolumn{5}{|l|}{ Presence of infrastructure } \\
\hline expressways & $\begin{array}{l}-0.343 \\
(-94.7)\end{array}$ & $\begin{array}{l}-0.363 \\
(-69.6)\end{array}$ & $\begin{array}{c}-0.107 \\
(-42.5)\end{array}$ & $\begin{array}{c}-0.149 \\
(-27.0)\end{array}$ \\
\hline railways & $\begin{array}{l}-0.580 \\
(-91.3)\end{array}$ & $\begin{array}{l}0.045 \\
(7.0)\end{array}$ & $\begin{array}{l}-0.371 \\
(-85.1)\end{array}$ & $\begin{array}{l}-0.303 \\
(-35.8)\end{array}$ \\
\hline \multicolumn{5}{|l|}{ Distance to infrastructure } \\
\hline expressway exit & $\begin{array}{l}0.041 \\
(33.0)\end{array}$ & $\begin{array}{l}0.122 \\
(61.3)\end{array}$ & $\begin{array}{l}0.050 \\
(56.6)\end{array}$ & na \\
\hline railway station & $\begin{array}{l}-0.137 \\
(-103.5)\end{array}$ & $\begin{array}{l}-0.121 \\
(-87.4)\end{array}$ & $\begin{array}{c}-0.118 \\
(-117.2)\end{array}$ & $\begin{array}{l}-0.179 \\
(-109.7)\end{array}$ \\
\hline New town dummy & $\begin{array}{r}1.126 \\
(264.0)\end{array}$ & $\begin{array}{l}0.738 \\
(101.0)\end{array}$ & $\begin{array}{l}1.632 \\
(366.0)\end{array}$ & $\begin{array}{l}1.083 \\
(121.6)\end{array}$ \\
\hline $\begin{array}{l}\text { Proximity to existing } \\
\text { single-family dwellings }\end{array}$ & $\begin{array}{r}0.731 \\
(548.0)\end{array}$ & $\begin{array}{c}0.537 \\
(242.1)\end{array}$ & $\begin{array}{l}0.828 \\
(934.1)\end{array}$ & $\begin{array}{l}0.878 \\
(300.8)\end{array}$ \\
\hline $\begin{array}{l}\text { Proximity to existing } \\
\text { multifamily dwellings }\end{array}$ & $\begin{array}{l}0.062 \\
(75.7)\end{array}$ & $\begin{array}{l}0.386 \\
(331.7)\end{array}$ & $\begin{array}{l}0.098 \\
(126.0)\end{array}$ & $\begin{array}{l}0.495 \\
(328.7)\end{array}$ \\
\hline Pseudo- $R^{2}$-statistic & 0.67 & 0.41 & 0.59 & 0.50 \\
\hline
\end{tabular}

na: not applicable.

Note: figures in parentheses are $t$-statistics.

railway stations tends to have a negative impact on the probability of residential construction in a zone. This can be explained partly by government policies to stimulate residential construction near railway stations. As indicated elsewhere (Rietveld, 2000) such a policy of building housing near railway stations certainly makes sense given the importance of nonmotorised transport modes as access modes to the railway network. For expressways, distance does not play such a clear role as a determinant of residential construction. The observed difference between the two modes makes sense: given the use of nonmotorised transport modes as access modes to a railway station compared with use of a car as an access mode to an expressway access point it is evident that proximity is more important in the case of railway stations. Last, the results show that spatial patterns of existing dwellings have a very strong impact on residential construction. New residences tend to be built in the immediate neighbourhood of existing residential areas. In addition to existing residential areas, new towns appear to have played an important role in residential construction between 1980 and 1995. For all market segments, the assignment of new-town (or growth-centre) status 
led to a strong increase in residential construction in the grid cells concerned. This result underlines the effectiveness of the new-town policy of the government during the 1980s (see section 3).

Given the stronger involvement of government in multifamily housing compared with single-family housing, as mentioned in section 4, one may expect that private concerns will be more strongly reflected in the locational patterns of single-family housing. This indeed appears to be so in the case of the variable relating to the presence of a railway. Construction of single-family housing is discouraged in zones with high levels of railway noise, but the opposite appears to be true of multifamily housing. This reflects a public sector concern with stimulating the development of settlements in such a way that open space is preserved as much as possible, even when this leads to a noise nuisance for the occupants of the newly constructed dwellings.

\subsubsection{Rest of the Netherlands}

Most of the results for the rest of the Netherlands are similar to those for the Randstad, differing mainly in the magnitude of the parameters. An important difference is that the accessibility to jobs in different sectors has a greater influence on the probability of residential construction. Given the lower density of jobs in the rest of the country, accessibility tends to play a more important role in the decisions of developers over where to locate new dwellings. In the rest of the Netherlands, forest and (wetland) nature conservation areas show a slight but clearly positive relationship to residential growth. Another difference is that the effect of the presence of a railway is negative both for single-family and for multifamily dwellings. This reveals that government concerns to preserve open space have higher priority in the Randstad (the densely populated part of the country) compared with the rest of the country.

\section{Conclusions}

Our analysis of the location of new residential areas broadly confirms the Alonsobased land-use theories described in section 2, indicating that growth takes place mainly at the fringes. The operational land-use models based on discrete representation of space appear to be useful tools for empirical research. They allow, among other things, the inclusion of factors such as proximity to local amenities and accessibility to mode-specific transport nodes to explain the location choice of developers.

The growth of residential areas has been substantial during the last century in the Netherlands. The emerging spatial patterns are the result of the preferences of consumers, governments, and real estate developers. Government policies have been aimed at preserving open space and preventing its fragmentation. During recent decades, governments have formulated strong policy instruments to achieve these aims, but market forces reflecting consumer preferences have also been strong. We have developed a model to analyse the probabilities that available land will be converted to residential use. The spatial pattern of construction during the period 1980-95 demonstrates that proximity to existing residential areas is important. This implies that growth is focused at the fringe of existing centres. This may not, as such, be a surprising result, but it is necessary to control for this factor in order to establish the impacts of other location factors. For example, we found that proximity to infrastructure access points (railway stations) also plays an important role. The consistently negative coefficient for the variable representing distance to railway stations reflects the influence of spatial planning that has been aimed at stimulating housing developments at these locations. For expressway exits, no such negative coefficient is found, which reveals that spatial planning in the Netherlands has indeed favoured locations near railway stations compared with expressway exits. The impact of the presence of 
natural areas is rather small. Outside the Randstad region residential construction tends to be attracted to natural areas but within the Randstad there are signs of opposing forces. This can be interpreted as an indication that in this part of the country government has discouraged residential construction in and near natural areas (including the so-called 'green heart'). Another clear signal of public sector influence on the choice of location of residential construction is that, in the Randstad, construction of multifamily housing is not repelled by the presence of railways in certain zones. This reveals the high priority of the public sector to stimulate the development of settlements at such places so that open space is preserved as much as possible, even when this leads to noise nuisance for occupants of the newly constructed dwellings. Another explanation for this result may be the initiatives of the Netherlands Railways real-estate company, that was quite active during the study period.

The empirical results we found for the period 1980-95 cannot simply be transferred to future periods because the preferences of actors may change. As already mentioned in section 3, the policy regime at the beginning of the period was rather different from the regime at the end, and since 1995 there have been additional policy changes. Most recent was the presentation of the fifth spatial planning memorandum (VROM, 2001) with its emphasis on 'urban networks'. One of the main ways to develop the analysis further would be to introduce government policies in a sharper way. This could be done by the explicit introduction of land-use restrictions for residential purposes. For example, hard constraints can be interpreted in the model given in section 4 as limitations on the choice set of locational alternatives from which developers and consumers may choose. Or, when government policies act as softer constraints, one might at least try to find out to what extent and under what conditions such policies appear to discourage real-estate development. Surprisingly, no accurate digital information is available at the national level of past spatial planning restrictions. However, for the present situation, substantial efforts are being made in the Netherlands to develop such a database. This would greatly enhance the opportunities for research in this area, in particular because it would allow for a more explicit comparison of market agents with public policy.

Acknowledgements. The authors thank the three referees for their constructive comments.

\section{References}

Aalbers R, Bettendorf L, Volleberg H, 1999, "Op grond van welvaart" [On the basis of welfare] Economisch Statistische Berichten 84(4233) D12 - D17

Alonso W, 1964 Location and Land Use (Harvard University Press, Cambridge, MA)

Anas A, 1982 Residential Location Markets and Urban Transportation (Academic Press, London)

Bontje M, Ostendorf W, 1999, "Plan, feit en haalbaarheid: de succeskansen van een voortgezet compactestadbeleid" [Plan, fact and feasibility: the chances of success for a continued compact city policy], in Voorbij de compacte stad? Eds F Dieleman, S Musterd (Van Gorcum, Assen) pp $75-86$

Brueckner J K, 2000, "Urban sprawl: diagnosis and remedies" International Regional Science Review 23160 - 171

Buurman J, Rietveld P, 2000 The Economics of Land Markets (Vrije Universiteit, Amsterdam)

CBS, 1997, "Statistiek van het bodemgebruik 1993" [Land-use statistics 1993], Centraal Bureau voor de Statistiek, Voorburg and Heerlen

Clark W A V, Kuijpers-Linde M, 1994, "Commuting in restructuring urban regions" Urban Studies $31465-483$

Cramer J, 1991 The Logit Model (Arnold, London)

Faludi A, van der Valk A J, 1994 Rule and Order: Dutch Planning Doctrine in the Twentieth Century (Kluwer Academic, Dordrecht)

Fujita M, 1989 Urban Economics (Cambridge University Press, Cambridge)

Garreau D, 1988 Edge City (Anchor Books, New York) 
Gerritsen R A, 1997 De Toenemende reistijd woon-werkverkeer: er zijn grenzen! [The increasing travel time of commuters: there are limits!] (Wereldhave, Den Haag)

Glaeser E, Kahn R, 2003, "Sprawl and urban growth", WP-9733, National Bureau of Economic Research, Cambridge, MA

Goetgeluk R, 1997 Bomen over wonen: Woningmarktonderzoek met beslissingsbomen [Talking about dwellings: housing market research with decision trees], thesis, Faculteit Ruimtelijke Wetenschappen, Universiteit Utrecht, Utrecht

Gordon P, Richardson H W, 1997, "Alternative views of sprawl: point; are compact cities a desirable planning goal?" Journal of the American Planning Association 63107 - 126

Hayashi Y, Roy J, 1996 Transport, Land Use and the Environment (Kluwer, Dordrecht)

Hayward S F, 1996, 'Preserving the American dream: the facts about suburban communities and housing choice", California Building Industry Association, 1215 K Street, Suite 1200, Sacramento, CA 95814

Henderson J V, 1985 Economic Theory and the Cities (Academic Press, New York)

Henderson V, Mitra A, 1996, "The new urban landscape developers and edge cities" Regional Science and Urban Economics $26613-643$

Hilbers H D, Verroen E J, 1993 Het beoordelen van de bereikbaarheid van locaties: definiëring, maatstaven, toepassing en beleidsimplicaties [Evaluating the accessibility of locations: definitions, criteria, application and policy implications] (TNO Inro, Deflt)

Maat K, 1999, 'Dilemma tussen doelstellingen van woningbouw en mobiliteit" [Dilemma between objectives of housing and mobility], in Voorbij de compacte stad? [Part the compact city?] Eds F Dieleman, S Musterd (Van Gorcum, Assen) pp 87-98

McCann P, 2001 Urban and Regional Economics (Oxford University Press, Oxford)

McFadden D L, 1978, "Modelling the choice of residential location", in Spatial Interaction Theory and Planning Models Eds A Karlsqvist, L Lundqvist, F Snickars, J W Weibull (North-Holland, Amsterdam) pp 75-96

Martinez F J, 2000, "Towards a land use and transport interaction framework", in Handbook of Transport Modelling Eds D A Hensher, K J Button (Pergamon, Amsterdam) pp 145-164

Mills E S, Hamilton B W, 1994 Urban Economics (Harper Collins College, New York)

Muth R, 1969 Cities and Housing (University of Chicago Press, Chicago, IL)

Needham B, 1997, "Land policy in the Netherlands" Tijdschrift voor Economische en Sociale Geografie $\mathbf{8 8} 291$ - 296

Needham B, Kruijt B, Koenders P, 1993 Urban Land and Property Markets in the Netherlands (UCL Press, London)

Nelson A C, 1999, "Comparing states with and without growth management: analysis based on indicators with policy implications" Land Use Policy 16121 - 127

Ottens H F L, 1999, “Verstedelijking en ruimtebeslag: naar een nieuw beleid"[Urbanisation and land use: towards a new policy], in Voorbij de compacte stad? Eds F Dieleman, S Musterd (Van Gorcum, Assen) pp $37-48$

Peiser R B, 1989, "Density and urban sprawl” Land Economics 65193 - 204

Razin E, 1998, "Policies to control urban sprawl: planning regulations or changes in the "rules of the game'?" Urban Studies 35(2) 321 - 340

Rietveld P, 2000, "The accessibility of railway stations: the role of the bicycle in The Netherlands" Transportation Research Part D 571 - 75

Rietveld P, Bruinsma F R, 1998 Is Transport Infrastructure Effective? (Springer, Berlin)

SCP, 2000, "Sociaal en Cultureel Rapport, Nederland in Europa" [Social and cultural report, The Netherlands in Europe], Social and Cultural Planning Office, The Hague

Van der Laan L, Vogelzang J, Schalke R, 1998, "Commuting in multi-nodal urban systems: an empirical comparison of three alternative models" Tijdschrift voor Economische en Sociale Geografie $89384-400$

Van der Vlist A J, 2001 Residential Mobility and Commuting (Tinbergen Institute, Amsterdam)

Van Ham M, 1999, "Waar moet dat heen? Bereikbaarheid als indicator" [Where to go? Accessibility as an indicator], Urban Research Centre, Utrecht University, Utrecht

Van Lierop W F J, 1985 Spatial Interaction Modelling and Residential Choice Analysis $\mathrm{PhD}$ dissertation, Vrije Universiteit, Amersterdam

Van Lierop W, 1989 Spatial Interaction Modelling and Residential Choice (Gower, Aldershot, Hants)

Van Ommeren J, 2000 Commuting and Relocation of Jobs and Residences (Ashgate, Aldershot, Hants) 
VROM, Ministry of Housing, Spatial Planning and the Environment [Ministerie van Volkshuisvesting, Ruimtelijke Ordening en Milieubeheer (VROM)]; formerly the Ministry of Housing and Spatial Planning (Staatsuitgeverij, The Hague)

1960 (Eerste) Nota inzake de Ruimtelijke Ordening [(First) spatial planning memorandum] 1966 Tweede Nota over de Ruimtelijke Ordening [Second spatial planning memorandum] 1974 Orienteringsnota Ruimtelijke Ordening [Spatial planning memorandum; orientation] 1988 Vierde nota over de Ruimtelijke Ordening [Fourth spatial planning memorandum] 1990 Vierde nota over de Ruimtelijke Ordening Extra [Fourth spatial planning memorandum extra]

2001 Vijfde nota over de Ruimtelijke Ordening [Fifth spatial planning memorandum]

Wagtendonk A J, Rietveld P, 2000 Ruimtelijke ontwikkelingen woningbouw Nederland, 1980 - 1995 [Spatial developments in residential construction, The Netherlands, 1980 - 1995] (Vrije Universiteit Amsterdam) 
